\title{
sciendo
}

\section{Study on the fiscal behavior at an international level}

\author{
Petre BREZEANU \\ The Bucharest University of Economic Studies, Bucharest, Romania \\ Petre.brezeanu@fin.ase.ro \\ Adriana Florina POPA \\ The Bucharest University of Economic Studies, Bucharest, Romania \\ adriana.popa@cig.ase.ro \\ Daniela Nicoleta SAHLIAN \\ The Bucharest University of Economic Studies, Bucharest, Romania \\ daniela.sahlian@cig.ase.ro \\ Monica Florentina CALOPEREANU \\ The Bucharest University of Economic Studies, Bucharest, Romania \\ monica.calopereanu@gmail.com \\ Ramona Tatiana DAMIAN \\ The Bucharest University of Economic Studies, Bucharest, Romania \\ damianramona12@yahoo.com
}

PICBE | 601

\begin{abstract}
Apparently, defining fiscal behavior is a relatively easy approach, but in essence, this concept requires the research of several elements, both economic and psychological. The taxpayer is the component of the tax system that reflects the fiscal policy and, implicitly, its changes. Thus, research in the field has shown that two types of behavior can be identified by combining several economic, psychological, religious or cultural factors: fiscal compliance or fiscal non-compliance. The research ideea may be motivated by the growing importance of tax behavior and compliance subject, especially in the current economic situation, when taxation has become a controversy at any time and in any society, regardless of the degree of democracy. Moreover, tax compliance does not refer only to the economic aspects, but also to the behavioral aspects that influence the process of raising public taxes. The econometric study analyzes the fiscal correlation between the public debt and tax variables such as tax revenues from direct and indirect taxes or social contributions, conected to the dynamics of the gross domestic product and the scale of payments balance. The study is conducted for two groups of countries: developed and emerging countries. The purpose of this research is to identify both the impact of tax revenues on direct, indirect taxes and social contributions, and that of the dynamics of gross domestic product and scale of payments balance on public debt, showing how fiscal behavior is influenced by the two groups of countries and what factors contribute to this.
\end{abstract}

Keywords: fiscal behavior, tax system, taxpayer, individual, taxpayer, tax revenue, fiscal policy, fiscal pressure

\section{Introduction}

Taxation has represented and continues to represent a major obstacle to the structural developments of the economic operator.

The fiscal behavior of the taxpayer has a psychological aspect and its effect depends on several elements, such as: the real amount of taxes and fees, the ability of the taxpayer to

DOI: 10.2478/picbe-2019-0053, pp. 601-612, ISSN 2558-9652| Proceedings of the $13^{\text {th }}$ International Conference on Business Excellence 2019 
assess the real tax burden, his attitude towards the state and taxation, the ability to use the administrative rules in hiss favor, as well as the degree of habit at the level of perceived taxation.

The taxpayer is the component of the tax system that reflects the fiscal policy and, implicitly, its changes. Whether they are an individual or a legal person, the taxpayer is compelled by law to transfer to the state budget some of the value that they create as a result of carrying out an activity.

When a taxpayer relates to the tax obligations decided through fiscal policy, two types of tax behavior can occur: tax compliance and tax non-compliance. According to Franzoni (2008), taxpayers usually have to fulfill simultaneously four conditions in order to comply with current tax legislation: first, a full tax base reporting, a correct determination of tax obligations, timely submission of tax returns, as well as the timely payment of the amounts they owe. Any deviation from one of these conditions gives rise to a tax non-compliance behavior.

In general, according to Kirchler (2007), the taxpayers' willingness to cooperate with the state and its institutions and to pay taxes depends on a variety of variables. While economists highlight the relevance of external variables, such as tax rates, income, probability of tax audits and the severity of fines, psychological research shows that internal variables are of similar importance. In this respect, studies show the importance of certain factors such as taxpayers' knowledge of tax legislation, attitudes towards government and taxation, personal norms, perceived social norms, fairness, and motivational tendencies to conform and discuss strategic intervention possibilities increasing tax compliance.

\section{Literature review}

Since ancient times, the concept of "politics" had more meanings. According to Bistriceanu D. (2001), the word "politics" derives from the Greek "politics" which referred to the administration of the society or the fortress. In the universal specialty literature, there have been several references made by economists to the term "politics," reminding Weimer D. here, in whose conception "policy" refers to concrete measures adopted by a state for offering solutions to the problems faced by society. In the Romanian specialized literature, the concept of "politics" is used in a generic sense and not in actual matters.

At the same time, the notion of taxation is seen by economists in both the universal and specialized literature as a complex one, finding its origins with the process of creation and functioning of the state, from its incipient forms up to the present, when the state has the obligation to fulfill its functions and multiple tasks in terms of efficiency.

Milton Friedman, professor of economic neoclassicism, was one of the representatives of the post-war period who elaborated the first tax theories. In the economic neoclassicism view, the tax was regarded as a financial variable and the concern was on the discovery of ways in which public spending could be covered in optimum conditions with the help of the income collected from the population.

According to Musgrave (1984) and Paredes, Pedregal and Pérez (2014), fiscal policy is a set of tax decisions that the state adopts in order to provide the financial resources needed for achieving its tasks. With regard to fiscal policy, Şaguna (2001) consideres that the most important role that taxation is knowing how to ensure the state and society's income without setting a burden or damage to private interests and property of individuals or legal persons.

DOI: $10.2478 /$ picbe-2019-0053, pp. 601-612, ISSN 2558-9652| Proceedings of the $13^{\text {th }}$ International Conference on Business Excellence 2019 
Over time, EU views have been divided into two important principles: one which refers to the European Community being organized as a confederation, ie as a union of independent states, and the second one which speaks of the tax system of the Community viewed from the perspective of fiscal federalism

According to the first principle, the European Community is a supranational organization, and therefore fiscal policy at Union level does not pursue the same objectives as a state's fiscal policy. Therefore, according to Tatoiu (2008), if the EU is seen as a confederation, the Community tax policy can be defined as a set of national fiscal policies coordinated within a well-defined area (EU area) in order to achieve compatibility of Member States taxes in order to ensure the smooth functioning of the common market. Under its treaties, the EU does not have the power to create or charge taxes, its role being just a secondary one in this regard. In order to achieve integration and a full economic union, the European institutions have drawn up a set of legal rules that ensure and complement the implementation of the provisions of the EC Treaty and form the so-called Community tax law. In essence, according to Minea and Coastaş (2006), this set of legal rules aims at achieving three objectives: to ensure Community control of national taxation for Member States or accession countries, to design a fiscal harmonization policy in these countries, and to apply contradictory mechanisms related to tax issues.

The second principle addresses the idea that the European Union is regarded as a federation and fiscal policy is considered to be that of a federal state, based on three levels of administrative bodies: federal, state and local. That is why, from this point of view, the European Union's fiscal policy is the set of regulations on the establishment and collection of taxes, duties and other tax resources. Nevertheless, EU does not currently have the ability to create taxes, this responsibility being left to the Member States. Therefore, as mentioned by Thisium (2008), the "establishment and collection of taxes" refers only to the identification and procurement of financial resources at the disposal of the Community, namely: customs duties on imports to the European Union, agricultural taxes, excise duties, a percentage of value added tax calculated on a harmonized basis.

Therefore, at the level of the European Union, fiscal policy must address two major problems, namely the current fiscal problems between the Member States and specific Community issues. In the first category there are the fiscal difficulties caused by the danger of double taxation and tax evasion, together with the problem of non-discriminatory use of taxes at the EU countries level. As for the second category, it should be pointed out that within the European Union the fiscal policy must take into account the interstate relations that take place in a single market where free movement is complete.

Similarly, the fiscal system in the European Union should be viewed from two perspectives: as a collection of national tax systems (in the idea of a confederation) or as a single system (in the context of the second principle of fiscal federalism). Thus, the tax system in the EU can be defined as a set of decisions by which the tax systems of the EU countries are considerably influenced and their compatibility is ensured in order to achieve the objectives set by the accession treaty. Currently, in the European Union, the fiscal system rather takes the form of a set of national tax systems rather than a federal single system.

\section{Methodology}

The database used in this study consists of data collected from the official database of the European Union - Eurostat, for a period of 9 consecutive years (the last 9 years, 2008-2016). DOI: $10.2478 /$ picbe-2019-0053, pp. 601-612, ISSN 2558-9652| Proceedings of the $13^{\text {th }}$ International Conference on Business 
The 9-year period was chosen to be able to present statistically significant data relevant to changes in European tax legislation but also to the one from each Member State.

The two groups of Member States of the European Union were analyzed for the entire period mentioned above but not all were EU members for all the analyzed years. However, this option was chosen because, as a general rule, a state which has joined the European Union more recently has adopted fiscal convergence measures long before a Member State becomes active.

After being collected, data was systematized and processed in an Excel database. We tracked the fiscal pressure expressed in percentages for each country in the two groups of EU member states (fiscal pressure related to indirect taxes, direct taxes and social contributions), the gross domestic product balance and the scale of payments and government debt, expressed as a percentage of GDP in order to facilitate comparability with the other regression model variables. The Eviews 7 econometric program was selected for the implementation of the study, both for model implementation and for making estimates.

\section{Data features}

The main characteristics of the variables are as follows:

- Quarterly Frequency;

- The 2008Q1-2016Q4 period (40 periods);

- They represent values of macroeconomic indicators calculated for 12 EU countries.

In order to make a comparative study, two groups of countries were formed:

- Group 1: consisting of developed countries, namely Germany, the United Kingdom, France, Belgium, the Netherlands, Italy;

- Group 2: Developing or emerging countries, namely: Poland, Romania, Hungary, Bulgaria, Czech Republic, Croatia.

- A number of 5 macroeconomic indicators (explanatory variables) and another indicator as a dependent variable were considered;

- The number of observations was 216.

Before the final model was established, a series of tests were carried out to calibrate the model and to establish the lags, starting from the assumption that the change in the variables influences the economy with a certain lag at macroeconomic level.

\section{Defining variables}

The dependent variable is represented by the dynamics of the public debt calculated quarterly and introduced into the model as a percentage change.

The independent or explanatory variables introduced into the model are as follows:

- The share of indirect taxes in GDP: ind_pib, the model taking into account its percentage change compared to the same period of the previous year;

- The weight of direct taxes in GDP: ind_pib, in the model was calculated its percentage change compared to the same period of the previous year;

- The share of social contributions in GDP: contr_pib, in the model was calculated its percentage change compared to the same period of the previous year;

- GDP dynamics;

- Scale of payments (export-import).

DOI: 10.2478/picbe-2019-0053, pp. 601-612, ISSN 2558-9652| Proceedings of the $13^{\text {th }}$ International Conference on Business 
After applying the first difference, all variables have been found to be stationary: $d\left(v^{2} r_{i}\right)=$ $v a r_{i}-\operatorname{var}_{1}(-1)$. The results of all applied stationary tests are presented in the annexes.

After the model was estimated for both groups, the Haussman test for random effects was performed. For both groups of countries, a probability test of approximately $36.6 \%$ (group 1) and $22.6 \%$ (group 2) was obtained, which means that the zero hypothesis can not be rejected, so it is preferable to apply random effects rather than fixed effects. Tests have shown that the best results are obtained with the application of temporal random effects (individual random effects led to a decrease in Rf2 adjusted for both groups of countries).

\section{Characteristics of the model}

The model used in this study is one with panel data, and the estimation was performed using the least squares method (OLS regression) using the Eviews 7 statistical analysis program. Such a model is formed by combining time series data with cross-sectional data. A model with panel data is described by the following equation:

$$
y_{i t}=\alpha+\beta x_{i t}+u_{i t}
$$

- $\quad y_{i t}$ represents the dependent variable, $\alpha$ constant, $\beta$ represents a vector $\mathrm{k} \times 1$ of the parameters to be estimated for the explanatory variables, and $\mathrm{x}$ it is a $1 \times \mathrm{k}$ vector of observations for the explanatory variables.

The model equation is as follows:

Datoria $_{P I B}=c+\beta_{1} B P_{P I B}+\beta_{2} C O N T R_{P I B}+\beta_{3} D I R_{P I B}+\beta_{4} I N D_{P I B}+\beta_{5} P I B+\varepsilon_{i}$

Where: Datoria $_{\boldsymbol{P I B}}$ - share of public debt in GDP,

$\mathrm{BP}_{\mathrm{PIB}}$ - Balance of payments (export-import),

CONTR $_{\mathrm{PIB}}$ - share of social contributions in GDP,

$\mathrm{DIR}_{\mathrm{PIB}}$ - share of direct taxes in GDP,

IND $_{\text {PIB }}$ - share of indirect taxes in GDP,

PIB - GDP dynamics,

$\varepsilon_{\mathrm{i}}$ - Residue vector (model errors).

\section{Results and discussions}

Model results for Group 1 countries (Germany, United Kingdom, France, Belgium, Netherlands, Italy)

Table 1 shows that the estimated model for the group of developed countries is statistically valid according to the F statistic and its associated probability (we reject the null hypothesis - all the regression variables are equal to zero and we accept the alternative hypothesis - at least a variable is statistically significant).

Also, the explanatory variables are statistically significant for the $1 \%$ and $10 \%$ thresholds.

To see to what extent the variance of the dependent variable (the share of government debt in GDP) is explained by the variation of the independent variables (balance of payments balance, share of social contributions in GDP, weight of direct taxes in GDP, weight of indirect taxes in GDP and GDP dynamics) the adjusted Rf2 coefficient was analyzed. Thus, we note that the explanatory variables determine the dependent variable according to Rf2 adjusted 
to $40.6 \%$. Moreover, according to the results recorded in the model and transposed in Figure 1 , the standard regression error has a value of 5.6\%. The standard regression error is the standard deviation of the residue and it is preferable to have a lower value.

Figure 1. Group 1: Germany, United Kingdom, France, Belgium, Netherlands, Italy

Dependent Variable: DATORIA_PIB

Method: Panel EGLS (Cross-section random effects)

Date: 06/01/17 Time: 15:14

Sample (adjusted): 200802201604

Periods included: 35

Cross-sections included: 6

Total panel (balanced) observations: 210

Swamy and Arora estimator of component variances

\begin{tabular}{ccccc}
\hline Variable & Coefficient & Std. Error & t-Statistic & Prob. \\
\hline \hline IND_PIB(-1) & 0.157999 & 0.095030 & 1.662615 & 0.0979 \\
DIR_PIB & -0.198147 & 0.072765 & -2.723100 & 0.0070 \\
OONTR_PIB & -0.178507 & 0.101922 & -1.751416 & 0.0814 \\
PIB & -0.013760 & 0.001699 & -8.099884 & 0.0000 \\
BP & $-6.43 E-07$ & $1.64 E-07$ & -3.917657 & 0.0001 \\
C & 0.050934 & 0.003941 & 12.92275 & 0.0000 \\
\hline
\end{tabular}

\begin{tabular}{|c|c|c|c|}
\hline \multicolumn{4}{|c|}{ Effects Specification } \\
\hline $\begin{array}{l}\text { Cross-section random } \\
\text { Idiosyncratic random }\end{array}$ & & $\begin{array}{l}1.62 E-09 \\
0.052320\end{array}$ & $\begin{array}{l}0.0000 \\
1.0000\end{array}$ \\
\hline \multicolumn{4}{|c|}{ Weighted Statistics } \\
\hline $\begin{array}{l}\text { R-squared } \\
\text { Adjusted R-squared } \\
\text { S.E of regression } \\
\text { F-statistic } \\
\text { Prob(F-statistic) }\end{array}$ & $\begin{array}{l}0.423011 \\
0.406418 \\
0.056096 \\
19.46686 \\
0.000000\end{array}$ & $\begin{array}{l}\text { Mean dependent var } \\
\text { S.D. dependent var } \\
\text { Sum squared resid } \\
\text { Durbin-watson stat }\end{array}$ & $\begin{array}{l}0.039108 \\
0.067357 \\
0.641936 \\
1.384281\end{array}$ \\
\hline \multicolumn{4}{|c|}{ Unweighted Statistics } \\
\hline $\begin{array}{l}\text { R-squared } \\
\text { Sum squared resid }\end{array}$ & $\begin{array}{l}0.423011 \\
0.641936\end{array}$ & $\begin{array}{l}\text { Mean dependent var } \\
\text { Durbin-Watson stat }\end{array}$ & $\begin{array}{l}0.039108 \\
1.384281\end{array}$ \\
\hline
\end{tabular}

Source: Own processing in the Eviews program 7

Table 1. Results - Group 1: Germany, United Kingdom, France, Belgium, Netherlands, Italy

\begin{tabular}{|c|c|c|c|c|c|}
\hline \multicolumn{6}{|c|}{ Dependent variable: The dynamics of the government debt ratio in GDP } \\
\hline $\begin{array}{l}\text { Explanatory } \\
\text { variable }\end{array}$ & Coefficient & \multicolumn{2}{|c|}{ Standard error } & t-Statistic & \\
\hline ind_pib(-1) & 0.1579 & \multicolumn{2}{|c|}{0.095} & 1.662 & $* * *$ \\
\hline dir_pib & -0.1981 & \multicolumn{2}{|l|}{0.072} & -2.723 & $*$ \\
\hline contr_pib & -0.1785 & \multicolumn{2}{|l|}{0.101} & -1.751 & $* * *$ \\
\hline pib & -0.0137 & \multicolumn{2}{|l|}{0.001} & -8.099 & * \\
\hline $\mathrm{bp}$ & -0.0000006 & \multicolumn{2}{|l|}{0.000} & -3.917 & * \\
\hline $\mathrm{c}$ & 0.0509 & \multicolumn{2}{|l|}{0.003} & 12.92 & * \\
\hline$R^{2}$ adjusted & 0.406 & \multicolumn{2}{|c|}{ Durbin-Watson stat } & 1.384 & \\
\hline F-statistic & 19.466 & \multicolumn{2}{|c|}{ Prob (F-statistic) } & 0.000 & \\
\hline Cross sections & 6 & Perioads & 40 & Remarks & 216 \\
\hline
\end{tabular}

Source: Own processing based on data provided by Eurostat.

In the table above, it can be noticed that in the case of Group 1 of developed countries, the increase in the share of indirect tax revenues has a positive correlation with the evolution of public debt.

At the same time, the evolution of direct tax revenues has the effect of diminishing public debt in developed countries. Considering also that the share of direct tax revenues in

DOI: 10.2478/picbe-2019-0053, pp. 601-612, ISSN 2558-9652| Proceedings of the $13^{\text {th }}$ International Conference on Business 
GDP is an important one (values between $12 \%$ and $16 \%$ of GDP in relation to values between $6 \%$ and $8 \%$ in the case of the share of indirect tax revenues in GDP), the fiscal pressure in these countries focusing on income taxation confirms the results obtained in this study. These assumptions also apply to income from social contributions, which in the analyzed countries have a high share of GDP (between $8 \%$ and 18\% of GDP).

As expected, the dynamics of gross domestic product has a negative impact on public debt developments, GDP growth contributes to a reduction in public debt. Also, an increase in the balance of payments balance contributes to a small extent to the diminution of public debt.

The figure below shows the evolution of government debt over the period analyzed for Group 1 countries.

Figure 2. Evolution of public debt in 2007-2016 - Group 1: Germany, United Kingdom, France, Belgium, Netherlands, Italy

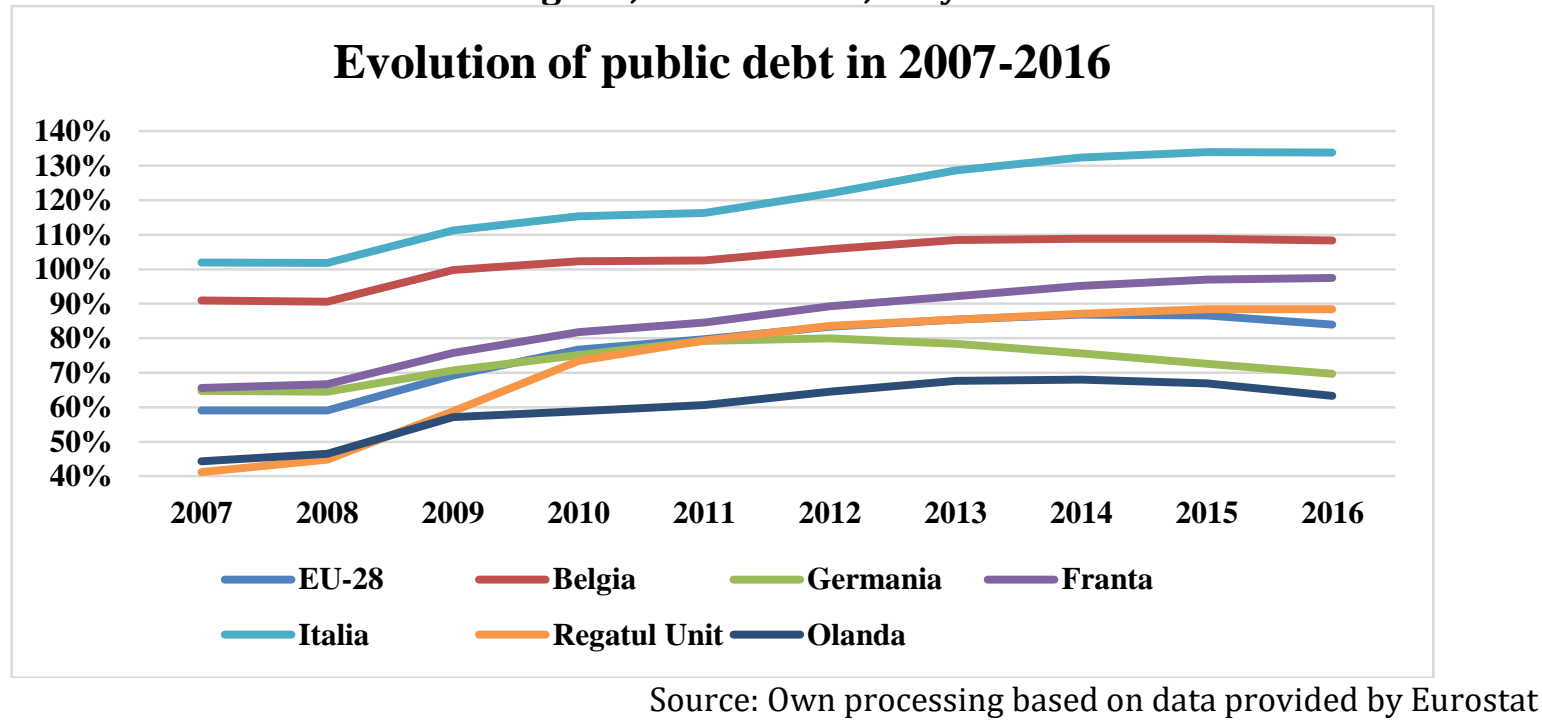

In the developed countries after the financial crisis, public debt increased significantly as a result of stronger ties between the economies of these states and the US according to the IMF (2016).

In conclusion, for the developed countries included in the study, during the analyzed period the main components of the tax revenues that contributed to the decrease of the public debt were represented by the direct taxes and the social contributions (budgetary surpluses allowed the reimbursement public debt). The results were also confirmed by the evidence that in the developed countries the emphasis is on income taxation and the maintenance of high quotas in the case of social contributions, to the detriment of indirect taxation (in situations of crisis, when consumption decreases the most affected category of tax revenues is represented by indirect tax revenues).

\section{Model results for Group 2 countries (Poland, Romania, Hungary, Bulgaria, Czech Republic, Croatia)}

Table 2 shows that the estimated model for the developed country group is statistically valid according to the F statistic and its associated probability (we reject the null hypothesis and 
accept the alternative hypothesis). Also, the explanatory variables are statistically significant for the $1 \%, 5 \%$ and $10 \%$ thresholds.

To see to what extent the variance of the dependent variable (the share of government debt in GDP) is explained by the variation of the independent variables (scale of payments balance, share of social contributions in GDP, weight of direct taxes in GDP, weight of indirect taxes in GDP and GDP dynamics) we analyzed the adjusted Rf2 coefficient. Thus, we notice that the explanatory variables determine the dependent variable according to Rf2 adjusted to a percentage of $37 \%$.

Moreover, according to the results recorded in the model and transposed in Figure 3, the standard regression error has a value of $10.51 \%$. We observe that in the case of developing countries, the standard error of regression is higher than for developed countries, so the standard deviation of the residue in this case is twice the value of the first group of countries.

Figure 3. Group 2: Poland, Romania, Hungary, Bulgaria, Czech Republic, Croatia Dependent Variable: DATORIA_PIB
Method: Panel EGLS (Period random effects)
Date: 05/28/17 Time: $19: 36$
Sample (adjusted): 200901201604
Periods included: 32
Cross-sections included: 6
Total panel (balanced) observations: 192
Swamy and Arora estimator of component variances

\begin{tabular}{|c|c|c|c|c|}
\hline Variable & Coefficient & Std. Error & t-Statistic & Prob. \\
\hline IND_PIE $(-3)$ & -0.266577 & 0.102268 & -2.606656 & 0.0099 \\
\hline DIR_PIE $(-4)$ & 0.127325 & 0.067564 & 1.884515 & 0.0611 \\
\hline CONTR_PIB $(-4)$ & -0.271580 & 0.141516 & -1.919082 & 0.0565 \\
\hline $\mathrm{PIB}$ & -0.018963 & 0.002469 & -7.680766 & 0.0000 \\
\hline $\mathrm{BP}$ & $-1.35 E-05$ & $5.51 E-06$ & -2.453908 & 0.0151 \\
\hline C & 0.084198 & 0.008674 & 9.707036 & 0.0000 \\
\hline \multicolumn{5}{|c|}{ Effects Specification } \\
\hline & & & S.D. & Rho \\
\hline Period random & & & 0.000000 & 0.0000 \\
\hline Idiosyncratic random & & & 0.105290 & 1.0000 \\
\hline \multicolumn{5}{|c|}{ Weighted Statistics } \\
\hline R-squared & 0.389253 & \multirow{5}{*}{\multicolumn{2}{|c|}{$\begin{array}{l}\text { Mean dependent var } \\
\text { S.D. dependent var } \\
\text { Sum squared resid } \\
\text { Durbin-watson stat }\end{array}$}} & 0.070035 \\
\hline Adjusted R-squared & 0.370147 & & & 0.123048 \\
\hline S.E. of regression & 0.105122 & & & 2.055402 \\
\hline F-statistic & 15.13931 & & & 1.369546 \\
\hline Prob(F-statistic) & 0.000000 & & & \\
\hline \multicolumn{5}{|c|}{ Unweighted Statistics } \\
\hline R-squared & 0.389253 & \multirow{2}{*}{\multicolumn{2}{|c|}{$\begin{array}{l}\text { Mean dependent var } \\
\text { Durbin-watson stat }\end{array}$}} & 0.070035 \\
\hline Sum squared resid & 2.055402 & & & 1.369546 \\
\hline
\end{tabular}

Source: Own processing in the Eviews program 7

Table 2. Results - Group 2: Poland, Romania, Hungary, Bulgaria, Czech Republic, Croatia

\begin{tabular}{|l|l|l|l|l|}
\hline \multicolumn{3}{|l|}{ Dependent variable: The dynamics of the government debt ratio in GDP } \\
\hline $\begin{array}{l}\text { Explanatory } \\
\text { variable }\end{array}$ & Coefficient & Standard error & t-Statistic & \\
\hline ind_pib(-3) & -0.266 & 0.102 & -2.606 & $*$ \\
\hline dir_pib(-4) & 0.127 & 0.067 & 1.884 & $* * *$ \\
\hline
\end{tabular}

DOI: 10.2478/picbe-2019-0053, pp. 601-612, ISSN 2558-9652| Proceedings of the $13^{\text {th }}$ International Conference on Business 


\begin{tabular}{|c|c|c|c|c|c|}
\hline contr_pib(-4) & -0.271 & \multicolumn{2}{|l|}{0.141} & -1.919 & $* * *$ \\
\hline pib & -0.018 & \multicolumn{2}{|l|}{0.002} & -7.68 & * \\
\hline $\mathrm{bp}$ & -0.0000135 & \multicolumn{2}{|l|}{0.000} & -2.453 & ** \\
\hline c & 0.084 & \multicolumn{2}{|l|}{0.008} & 9.707 & $*$ \\
\hline$R^{2}$ ajusted & 0.370 & \multicolumn{2}{|c|}{ Durbin-Watson stat } & 1.369 & \\
\hline F-statistic & 15.139 & \multicolumn{2}{|c|}{ Prob (F-statistic) } & 0.000 & \\
\hline Cross sections & 6 & Periods & 40 & Remarks & 216 \\
\hline
\end{tabular}

PICBE | 609

Source: Own processing based on data provided by Eurostat

The results obtained for Group 2 countries made up of countries in developed or emerging economies are changing from those obtained in developed countries. The increase in the share of indirect tax revenues has a negative correlation with the evolution of public debt. Therefore, an increase in indirect tax revenues contributes to the reduction of public debt, being correlated with the higher share of indirect tax revenues in GDP (between 11\% and $20 \%$ of GDP, compared to $11 \%$ and $16 \% \%$ in case of group 1). Similar to the Group 1 countries, in the case of the Group 2 countries the results indicated that the income from social contributions also contributes to the reduction of public debt.

At the same time, the evolution of direct tax revenues has the effect of increasing the public debt in case of Group 2 states, the tax burden on income tax being lower than that recorded for Group 1.

As expected, the dynamics of gross domestic product has a negative impact on public debt developments, its growth contributing to a reduction in public debt. Also, an increase in the scale of payments balance contributes to a small extent to the decrease of public debt.

The figure below shows the evolution of the government debt over the period analyzed in Group 2 countries.

Figure 4. Evolution of public debt in 2007-2016 - Group 2: Poland, Romania, Hungary, Bulgaria, Czech Republic, Croatia

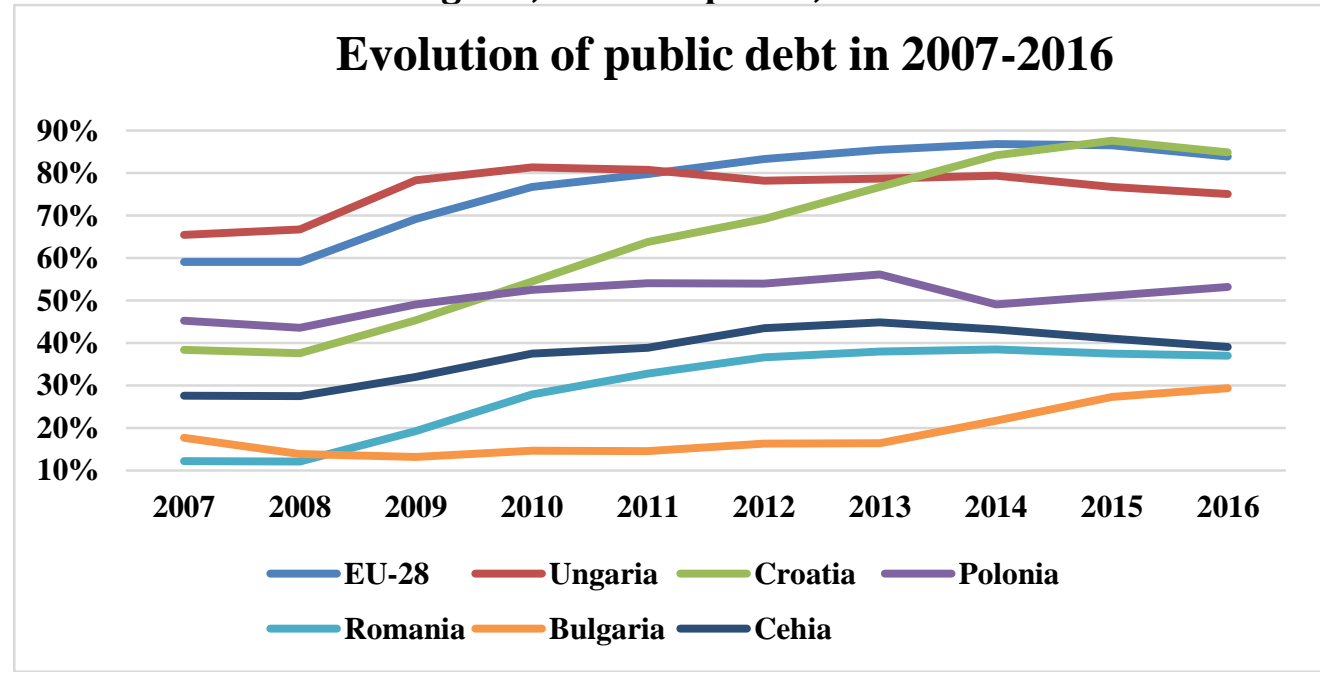

Source: Own processing based on data provided by Eurostat 
In emerging countries, after the financial crisis, public debt has increased, but in a smaller proportion as in the case of developed countries.

As a conclusion, for the developing and emerging countries covered by the study, during the analyzed period, the main components of the tax revenues that contributed to the diminution of the public debt were the indirect tax and social contributions revenues. The results were also confirmed by the evidence that in the developed countries the emphasis is on consumption taxation and the maintenance of high quotas for social contributions, to the detriment of direct taxation. As mentioned at the end of the analysis for Group 1 states, indirect tax revenues tend to be very fluctuating in times of crisis when consumption fluctuates and is not a long-term sustainable policy as in the taxation of direct tax revenues slightly fluctuating during economic shocks compared to indirect tax revenues).

Following the study, we observed a number of issues that define the fiscal behavior of the two groups of countries. Thus, for developed countries there is a tax behavior oriented towards direct taxation, that contributes to the diminution of public debt during the analyzed period. The results for the group of developed countries reflect the idea that the increase in the share of indirect tax revenues has a positive correlation with the evolution of public debt.

At the same time, in the case of emerging countries, the preference for tax revenues from indirect taxes is observed, but this is not a long-term sustainable behavior in meeting the budget deficit and public debt targets, but only in the medium and long term. The results obtained for this group of countries highlight the fact that, here, the increase in the share of indirect tax revenues has a negative correlation with the evolution of public debt.

In contrast, for both groups of countries, the only common point they have in fiscal behavior is the income from social contributions that contribute to the diminution of public debt both in the developed country group and in the emerging economies.

\section{Conclusion}

Tax behavior across different states is a delicate subject, as it involves both the analysis of economic and financial factors and the analysis of psychological, religious and cultural factors. Studies in the field usually address this issue only in a single way that is how fiscal policies influence the economic environment in which taxpayers operate, or how taxpayers react to fiscal policies through perceptions, attitudes and actions.

Over the years, many governments have tried to increase tax compliance by adopting an intransigent attitude towards all taxpayers, and by enacting laws and regulations to sanction and find tax evasion among taxpayers through different surveys or increasing company tax control. Reality shows that these means of enforcement proved to be unsuccessful in increasing the collection rate of taxes. Therefore, after a while, the governments of the European Union countries, especially developing countries, have realized that a change is needed to increase the amount of taxes collected. Thus, using appropriate strategies based on understanding the reasons for compliance decisions is more helpful than strictly enforcing laws and regulations. In this respect, we aimed to highlight the different reasons or determinants that influence the behavior of taxpayers. Research has shown that any government needs to analyze its legislation in terms of transparency and understandability. Taxpayers are faced with tax law before deciding to respect it, so it is very important for them to understand it. Studies show that tax law is hard to understand and generates uncertainty not only for ordinary citizens but also for tax authorities.

DOI: 10.2478/picbe-2019-0053, pp. 601-612, ISSN 2558-9652| Proceedings of the $13^{\text {th }}$ International Conference on Business 
Our econometric study revealed a tax behavior oriented towards direct taxation for the developed countries, that contributes to the diminution of the public debt during the analyzed period. In the case of the emerging countries the preference for indirect tax revenues was observed. Developing countries should tend towards the same behavior as developed countries because at the moment it seems to be sustainable in terms of meeting budget deficit and debt targets on medium and long term. As shown by the analysis carried out with the econometric model, the only common point in the fiscal behavior between the two groups of countries is represented by the income from the social contributions that contribute to the diminution of the public debt. Consequently, moving towards more intensive tax pressure on income tax has contributed to a reduction in public debt in the developed countries, while the focus on consumption tax in emerging countries has led to a higher level of public debt.

In conclusion, the first step that should be taken to ensure high tax compliance in developing countries is to formulate a clear legislation without uncertainty, followed by a decrease in corporate taxes and contributions in order to boost employment, and also by allowing deductible expenses, including those for research and innovation. At the same time, for sustainable long-term behavior, emerging economies should shift their focus to direct taxation as a state based on indirect tax revenues will meet its budget deficit and debt targets only on short and medium term. Certainly, fiscal policy can never achieve perfection, but of course, if understood by both sides, it can contribute to a high level of collection and compliance.

\section{References}

Bistriceanu D. Gh., Adochitei M.N., (2001), Negrea E., Finanţele agenţilor economici, Editura Economică.

Brezeanu P., (2010), Fiscality. Concepts, theories, policies and practical approaches, Wolters Kluwer Publishing.

Bunescu L., (2011), International Financing Alternatives for Romanian Central Government, Studies in Business and Economics, vol. 6.

Cioponea M., (2014), Finanțe publice și fiscalitate, Editura Fundației România de mâine.

Minea Ş.M., Coastaş C.F., (2006), Fiscalitatea în Europa la începutul mileniului III, Editura Rosetti.

Musgrave R., A., (1984), Public finance in theory and practice, McGraw Hill Higher Education Publishing.

Șaguna G., D., (2001), Tratat de drept financiar și fiscal, Editura All Beck.

Trandafir, A., Brezeanu, P., (2011), Optimalitatea politicii fiscale în România din perspectiva curbei Laffer, Economie teoretică şi aplicată, Volumul XVIII, Nr. 8/(561).

Braga V., Zărnescu O., (2012), Fiscal pressure in Romania, developments and effects, Annals of the University of Craiova, Economic Sciences Series.

Džakula M., Karalić A., (2013), The Fiscal Policy and the Public Debt - Cause of the Budget Balance, International Journal of Finance and Accounting

Franzoni A. L., (2008), Tax compliance, Encyclopedia of Law and Economics.

Gyorgy A., (2012), Social contributions in Romania, Romanian Joural of Fiscal Policy, Vol.2.

Hofmann E., Hoelzl E., Kirchler E., (2014), Preconditions of Voluntary Tax Compliance: Knowledge and Evaluation of Taxation, Norms, Fairness, and Motivation to Cooperate, Journal of Psychology.

DOI: $10.2478 /$ picbe-2019-0053, pp. 601-612, ISSN 2558-9652| Proceedings of the $13^{\text {th }}$ International Conference on Business Excellence 2019 
Ifo Istitute - Center for economic studies, (2014), Political institutions and fiscal policies, Journal for institutions comparisons, vol. 12.

IMF, (2016), Debt - Use it wisely, World economic and financial surveys, Fiscal Monitor.

Kirchler E., Hölzl E., Wahl I., (2009), Enforced versus voluntary tax compliance: The "slippery slope" framework, Journal of Economic Psychology.

Kumar M., Woo J., (2010), Public Debt and Growth, IMF Working Paper, No. 174/(10).

PICBE | 612

Mihaiu M., D., (2014), Analysis of public debt in the European Union - issues related to its sustainability, Journal of International Studies.

Padovano F., Galli E., (2010), Tax rates and economic growth in the OECD countries, Economic Inquiry, Vol. No. 1

Paredes J., Pedregal D., Pérez J., (2014), Fiscal policy analysis in the euro area: Expanding the toolkit, Journal of Policy Modeling, Vol. No. 5.

Sichigea D., F., (2014), Considerations on fiscal policy at the level of the European Union, Finance- challenges of the future Review, Year V, no.5.

Tatoiu A., M., (2008), Armonizarea sistemelor fiscale în contextul integrării în Uniunea Europeană, Teză de doctorat.

Todor S., P., Dumiter F., C., Brezeanu P., (2016), The influence of fiscal pressure on the taxpayers behavior, Revista Economică.

Vintilă G., Țibulcă I., L., (2014), A study on the evolution of tax pressure in Romania, Scientific Annals of the "Alexandru Ioan Cuza" University of Iaşi Economic Sciences.

Welch M.,R., Xu Y.L., Bjarnason T., O'Donnell P., (2010), "But everybody does it...”: the effects of perceptions, moral pressures, and informal sanctions on tax cheating, Sociological Spectrum.

Wenzel M., (2010), An analysis of norm processes in tax compliance, Journal of Economic Psychology. 